\title{
KEMAJEMUKAN DALAM POLITIK ETNIS MASYARAKAT URBAN (Studi Pada Masyarakat Multi Etnik dan Agama di Kota Metro)
}

\author{
Firmansyah \\ Fakultas Hukum, Institut Agama Islam Negeri Metro \\ e-mail: firmansipmh@gmail.com
}

\begin{abstract}
ABSTRAK
Dapat dikatakan bahwa politik adalah upaya untuk menentukan aturan yang dapat diterima oleh beberapa warga negara untuk membawa orang ke dalam kehidupan yang harmonis. Dalam menyusun penelitian ini, penulis menggunakan jenis penelitian lapangan. Karakteristik masyarakat sosial-politik para pendatang di Kota Metro masih cenderung membuat kelompok-kelompok berdasarkan ikatan emosional, ini terjadi karena kesamaan yang mereka miliki, tetapi proses pembauran dengan interaksi lingkungan sosial berjalan dengan baik. Tetapi kesadaran akan jumlah mereka masih belum bisa bersaing dalam perebutan kursi di parlemen. Di Kota Metro di mana pluralisme etnis tinggi, posisi kekuatan politik sentral masih dipegang oleh masyarakat adat. Kehadiran mereka dalam politik telah menunjukkan upaya untuk dapat bersaing dan dengan masyarakat adat memajukan Kota Metro dalam berbagai aspek kehidupan

Kata Kunci: pluralisme; etnik politik; masyarakat perkotaan
\end{abstract}

\begin{abstract}
It can be said that politics is an attempt to determine the rules that can be accepted by some citizens to bring people into a harmonious life. In preparing this research, the authors use the type of field research. Characteristics of sociopolitical societies of immigrants in Metro City still tend to make groups based on these emotional bonds occur because of the similarity they have, but the process of intermingling with the interaction of the social environment goes well. But the awareness of the amount of quantity they still cannot compete in the seizure of seats in parliament. In Metro City where ethnic pluralism is high, the position of central political power is still held by indigenous people. Their presence in politics has demonstrated an effort to be able to compete and with indigenous peoples advancing the Metro City in various aspects of life.
\end{abstract}

Keywords: Pluralism; Ethnic Politics; Urban Society

\section{PENDAHULUAN}

Demokrasi tidaklah berdasar atas hak-hak mayoritas, tapi suatu pengakuan bahwa semua adalah bagian dari suatu negara. Semua warga negara mempunyai hak, bahkan bukan hanya sekedar hak tetapi semacam dignitas politik supaya jangan sampai ada anggapan orang lain sebagai musuh dengan melihat kondisi masyarakat Indonesia yang majemuk serta realitas pluralitas tumbuh di dalamnya. Kegagalan untuk mengakomodir pluralitas akibatnya adalah masifikasi kekerasan dan potensi konflik horizontal. Kerjasama antara kesatuan sosial yang ada di masyarakat, dan antara masyarakat dengan negara untuk memperbesar dan melembagakan tradisi toleransi menjadi upaya mendesak yang harus dilakukan. Kekuatan terwujud dalam strukturstruktur hubungan kekuatan, baik pada tingkat nasional maupun pada tingkat-tingkat lokal. Bila kita melihat minoritas dalam kaitan atau pertentangannya dengan mayoritas maka yang akan dihasilkan adalah hubungan mereka yang populasinya besar (mayoritas) 
dan yang populasinya kecil (minoritas). Perspektif ini tidak akan dapat memahami mengapa golongan minoritas didiskriminasi. Karena besar populasinya belum tentu besar kekuatannya. ${ }^{1}$

Eksistensi etnisitas dalam labelisasi politik Indonesia kontemporer paling tidak dapat ditemukan dalam tiga dimensi utama: Pertama, tuntutan pengakuan identitas etnis; Kedua, adanya semacam keinginan untuk tetap mempertahankan identitas etnis dan agama antar kelompok; Ketiga, perjuangan terhadap perlindungan hak-hak masyarakat adat terhadap eksploitasi sumber daya alam yang mereka miliki. Dalam proses politik dan demokrasi, masalah ini kemudian memunculkan banyak regulasi maupun perundangan-undangan untuk mengatur sampai mengakomodir persoalan adanya realitas etnisitas dalam lingkungan sosio-politik di Indonesia.

Fenomena politik yang bernuansa etnis di Kota Metro merupakan salah satu dari sekian banyak fenomena politik di tanah air yang mengupas gencarnya semangat kembali ke etnisitas. Maraknya kembali ke etnisitas akhir-akhir ini kembali menghiasi panggung politik Indonesia terutama pada tataran lokal, di mana sebagian kalangan malah mengkhawatirkan akan kembali melahirkan ancaman terhadap integrasi dan keutuhan bangsa.

Munculnya dinamika sosial-politik di Kota Metro sebagai salah satu kota pada masa sebelumnya merupakan sasaran transmigrasi dan banyaknya masyarakat pendatang memunculkan potensi pergesekan keagamaan dan kesukuan seperti yang telah banyak diulas serta kuatnya penonjolan simbol-simbol primordial dalam pertarungan politik pada tataran lokal. Dari aspek partisipasi politik, masyarakat pendatang, masih kurang diakomodasi dalam memainkan peran dan kedudukan dalam pranata politik, beberapa kedudukan politis dan birokrasi masih didominasi oleh masyarakat setempat yakni masyarakat Lampung. Meski masyarakat pendatang seperti Tionghoa, Padang dan Jawa masih minoritas namun kedudukan dan peran mereka dalam tumbuh berkembangnya Kota Metro cukup memberikan kontribusi.

${ }^{1}$ Parsudi Suparlan. "Masyarakat Majemuk, Masyarakat Multikultural dan Minorotas". Makalah. Dalam Workshop Yayasan Interseksi "Hak-hak Minoritas dalam Landscape Multikultural" pada tanggal 5 Desember 2016, h. 7.

\section{METODE PENELITIAN}

Dalam menyusun penelitian ini, penulis menggunakan jenis penelitian lapangan (field research), yaitu penelitian yang dilakukan pada data yang berwujud kasus-kasus. Hal ini dilakukan untuk menjelaskan berbagai macam persoalan-persoalan yang berkenaan dengan pokok permasalahan yang dikaji. Sifat penelitian ini adalah deskriptif analitis. Penelitian ini melakukan analisis hanya sampai pada taraf deskripsi, yaitu penelitian deskripsi berusaha memberikan dengan sistematis dan cermat faktafakta aktual dengan sifat populasi tertentu. ${ }^{2}$

Selanjutnya menurut Irawan Soehartono, deskripsi yaitu menganalisis dan menyajikan fakta secara sistematis sehingga dapat lebih mudah untuk dipahami dan disimpulkan. ${ }^{3}$ Sedangkan analitis adalah menguraikan sesuatu dengan sangat cermat terarah sesuai dengan hasil informasi yang lengkap dari sebuah penelitian, yang bersifat membentangkan fakta-fakta kondisional dan dicerminkan dari suatu peristiwa. $^{4}$

Secara umum penelitian dengan metode kualitatif merupakan penelitian non hipotetis, maka proses analisis datanya seperti yang dikemukakan Lexy Moleong adalah proses mengorganisasian dan mengurutkan data ke dalam pola kategori dan susunan uraian dasar sehingga dapat menemukan hipotesis kerja yang disarankan oleh data. ${ }^{5}$

\section{PEMBAHASAN \\ Politik Etnis}

Dapat dikatakan bahwa politik (politics) adalah usaha untuk menentukan peraturan-peraturan yang dapat diterima baik oleh sebagian warga untuk membawa masyarakat ke arah kehidupan yang harmonis. Usaha untuk mencapai the good life ini menyangkut bermacam-macam kegiatan antara lain menyangkut proses penentuan tujuan dari sistem serta cara-cara melaksanakan tujuan itu. Masyarakat mengambil keputusan mengenai apakah

${ }^{2}$ B. Ahmad Soebani. (2009). Metode Penelitian Hukum. Bandung: Pustaka Setia, h. 57.

${ }^{3}$ Irawan Soehartono. (1999). Metode Penelitian Sosial Suatu Teknik Penelitian Bidang Kesejahteraan Sosial Lainnya. Bandung: Remaja Rosda Karya, h. 63.

${ }^{4}$ Noeng Muhajir. (1989). Metode Penelitian Kuantitatif. Jakarta: Rake Sarasin, h. 43.

${ }^{5}$ Lexy Moleong. (2000). Metodologi Penelitian Kualitatif. Bandung: Remaja Rosda Karya, h. 23. 
yang menjadi tujuan sistem politik itu dan hal yang menyangkut pilihan antara beberapa alternatif serta urutan prioritas dari tujuan-tujuan yang telah ditentukan.

Perilaku politik dapat dirumuskan sebagai kegiatan yang berkenaan dengan proses pembuatan dan pelaksanaan keputusan politik. Interaksi antara pemerintah dan masyarakat, antar lembaga pemerintah dan antara kelompok dan individu dalam masyarakat dalam rangka pembuatan, pelaksanaan, dan penegakan keputusan politik pada dasarnya merupakan perilaku politik. ${ }^{6}$

Sejalan dengan pengertian politik, perilaku politik berkenaan dengan tujuan suatu masyarakat, kebijakan untuk mencapai suatu tujuan, serta sistem kekuasaan yang memungkinkan adanya suatu otoritas untuk mengatur kehidupan masyarakat ke arah pencapaian tujuan tersebut. Beberapa negara berkembang sering dihadapkan dengan masalah integrasi nasional yang menjadi tantangan dalam pembangunan sistem politik di negara tersebut. Hal tersebut dapat dilihat dari dua dimensi, yakni: dimensi horizontal dan vertikal.

Perilaku politik dapat diartikan sebagai keseluruhan tingkah laku politik para aktor politik dan warga negara yang dalam manifestasi konkretnya telah saling memiliki hubungan dengan kultur politik. Sikap warga negara, respon dan aktivitasnya terhadap sistem politik yang berlaku dipengaruhi oleh budaya politik yang membentukanya. ${ }^{?}$

Perilaku politik (political behavior) dinyatakan sebagai suatu telaah mengenai tindakan manusia dalam situasi politik. Perilaku politik juga sering dikaitkan dengan proses pembuatan dan pelaksanaan keputusan politik. Adapun yang melakukan kegiatan politik adalah pemerintah dan masyarakat sesuai dengan fungsinya masing-masing. Pada hakikatnya seorang individu atau masyarakat setelah memiliki sikap politik terhadap suatu objek politik sebagai manifestasi nyata dari sikap politik yang merupakan sikap alami yang terdapat pada setiap individu. Melakukan tindakan atau aktivitas politik lalu

\footnotetext{
${ }^{6}$ Jean Kristiadi. (2006). Pemilihan Umum dan Perilaku Pemilih di Indonesia. Jakarta: Prisma, h. 28.

${ }^{7}$ Samuel P. Hutington dkk. (2010). Partisipasi Politik di Negara Berkembang. Jakarta: Rineka, h. 42.
}

tindakan ini yang kemudian disebut sebagai perilaku politik. ${ }^{8}$

Berdasarkan beberapa definisi perilaku politik menurut para ahli tersebut, dengan demikian dapat disimpulkan bahwa perilaku politik merupakan tindakan yang dilakukan pemerintah maupun masyarakat berkaitan dengan tujuan suatu masyarakat, kebijakan untuk mencapai suatu tujuan, serta sistem kekuasaan yang memungkinkan adanya suatu otoritas untuk mengatur kehidupan masyarakat kearah pencapaian tujuan tersebut.

Faktor-faktor yang mempengaruhi perilaku politik aktor politik (pemimpin, aktivis, dan warga biasa) antara lain: Lingkungan sosial politik tak langsung seperti sistem politik, ekonomi, budaya dan media massa; Lingkungan sosial politik langsung yang membentuk kepribadian aktor seperti keluarga, agama, sekolah, dan kelompok bergaul. Dari lingkungan ini, seorang aktor politik mengalami proses sosialisasi dan internalisasi nilai dan norma masyarakat dan norma kehidupan bernegara; Struktur kepribadian. Hal ini tercermin dalam sikap individu (yang berbasis pada kepentingan, penyesuaian diri dan eksternalisasi); Lingkungan sosial politik langsung berupa situasi yaitu keadaan yang mempengaruhi aktor secara langsung ketika hendak melakukan suatu kegiatan seperti cuaca, keadaan keluarga, keadaan ruang, kehadiran orang lain, suasana kelompok, dan ancaman dengan segala bentuknya. ${ }^{9}$

Munculnya politik etnis diawali tumbuhnya kesadaran orang yang mengidentikkan diri mereka ke dalam salah satu kelompok etnis tertentu, yang kesadaran itu memunculkan solidaritas kelompok. Dari teoritisi poststrukturalis kemudian postmodernitas yang mengkritik modernitas khususnya terhadap wacana etnis dalam konteks politik (ethnic politic).

Politik Etnis adalah tindakan politik yang diarahkan dengan menggunakan etnis sebagai kekuatan politik. ${ }^{10}$ Alesina Baqir dan Easterly berpendapat bahwa kelompok etnik punya pilihan yang berbeda dalam sumber daya publik, dan keanekaragaman seperti itu mengarah ketetapan

${ }^{8}$ Efriza. (2012). Political Explore: Sebuah Kajian Ilmu Politik. Bandung: Alfabeta, h. 25.

9 Oka Mahendra. (2005). Pilkada di Tengah Konflik Horizontal. Jakarta: Millenium Publisher, h. 41.

${ }^{10}$ Muhammad Asfar. (2006). Pemilu dan Perilaku Memilih 1955-2004. Surabaya: Pustaka Eureka, h. 31. 
kumpulan yang lebih rendah. Feron menunjukkan jika kelompok etnik mayoritas dan minoritas dalam keadaan yang baru mengantisipasi pilihan yang bertentangan pada beberapa kebijakan publik, kemudian etnik mayoritas punya masalah dalam melakukan kebijakan dua sisi tersebut mengarah pada konflik kekerasan. Konflik etnik muncul ketika bentuk koalisi etnik untuk membagi suatu keuntungan besar dan hasrat sumber daya umum, yang susah dijelaskan dalam model-model di mana tindakan datang dari asumsi mengenai pilihan berlawanan pada jenis sumber daya.

Kelompok mayoritas atau kelompok dominan dalam suatu masyarakat merupakan kelompok yang merasa memiliki kontrol atau kekuasaan untuk mengontrol. Konsep mayoritas sering dihubungkan dengan dominant culture. Konsep mayoritas menurut Gollnick dan Chinn dipahami sebagai sebuah aspek yang berkaitan dengan kehidupan kita, terutama dalam interaksi antar manusia. ${ }^{11}$ Definisi mayoritas adalah himpunan bagian dari suatu himpunan yang jumlah elemen didalamnya mencapai lebih dari separuh himpunan tersebut. Mayoritas bisa dibedakan dengan pluralitas, yang berarti himpunan bagian yang lebih besar daripada himpunan bagian lainnya. Lebih jelasnya, pluralitas tidak bisa dianggap mayoritas jika jumlah elemennya lebih sedikit daripada separuh himpunan tersebut. Dalam bahasa Inggris Britania, mayoritas (majority) dan pluralitas (plurality) sering disamakan dan kata mayoritas juga kadang dipakai untuk menyebut margin kemenangan, yaitu jumlah suara yang memisahkan pemenang pertama dan pemenang kedua.

Pendekatan situasional dalam melihat berdasarkan rasional choice, di mana etnisitas adalah sesuatu yang relevan dalam suatu situasi tapi tidak dalam situasi yang lain, seseorang boleh memilih menjadi anggota etnis apabila mereka menemukan keuntungan dari kelompok etnis tersebut.

Suatu pandangan yakni primordialist menguraikan bahwa tidak diperlukan penjelasan mengapa etnisitas seringkali berbentuk basis diskriminasi dan mobilisasi politik, kelompok etnis secara natural adalah politik, sebab keduanya mempunyai akar biologis atau karena kedua-duanya diatur dalam budaya dan sejarah sebagai suatu yang

${ }^{11}$ Alo Liliweri. (2005). Prasangka dan Konflik. Yogyakarta: LKiS, h. 102. terberi dan tidak dapat diubah dalam kehidupan sosial politik. Dengan kata lain primodialisasi berasumsi bahwa kategori etnik pasti selalu berhubungan dengan sosial, dan kaitannya dengan politik secara otomatis diikuti dengan hubungan sosial. Objek utama argumen primordialist bahwa mereka tidak dapat membuat perasaan berbeda dalam politik etnis dalam ruang dan waktu. ${ }^{12}$

Kata etnis berasal dari kata ethnos yang dalam bahasa Yunani berarti "masyarakat". ${ }^{13}$ Etnis adalah golongan masyarakat yang didefinisikan secara sosial berdasarkan berbagai macam karakteristik kulturnya. Etnisitas atau kesukubangsaan selalu muncul dalam konteks interaksi sosial pada masyarakat majemuk. ${ }^{14}$ Dalam proses sosial kelompok etnik akan memanfaatkan atribut-atribut sosial-budaya yang dimiliki untuk mencapai tujuan tertentu. Manifestasi etnisitas sering menimbulkan ketegangan dan konflik sosial di antara pihak-pihak yang terlibat atau yang berkepentingan.

\section{Kelompok Masyarakat Pendatang}

Masyarakat sebagai kumpulan individu-individu yang mempunyai suatu sistem sosial keseluruhan, di mana para anggotanya memiliki tradisi budaya dan bahasa yang sama. Tetapi dalam suatu sistem sosial yang kompleks seperti halnya di Kota Metro sering pula kita jumpai golongan minoritas etnis dan orang-orang pendatang, sehingga kita perlu berbicara tentang tradisi budaya dan bahasa yang dominan. Dapat diperkirakan bahwa setiap orang memiliki budaya yang sama, "batas" dari masyarakat tersebut tanpa keraguan dan dapat ditentukan dengan baik.

Masyarakat dalam perspektif difusi (penyebaran) dibagi dua menjadi masyarakat pribumi dan masyarakat pendatang. Masyarakat pribumi adalah sekelompok manusia yang tinggal dan menetap lama dan memiliki ikatan sejarah emosional dengan wilayahnya, dapat dikatakan sebagai masyarakat asli. Sedangkan masyarakat pendatang adalah sekelompok manusia yang melakukan perpindahan ke suatu wilayah dan tinggal serta beradaptasi dalam

\footnotetext{
${ }^{12}$ James D. Fearon. (2004). Ethnic Mobilization and Ethnic Violence. Departement of Political Science Stanford University,

13 Amin Abdullah. (2005). Pendidikan Multikultural. Yogyakarta: Pilar Media, h. 193.

${ }^{14}$ Rusmin Tumanggor dkk. (2010). Ilmu Sosial dan Budaya Dasar. Jakarta: Kencana, h. 110.
} h. 6 . 
proses interaksi bersama masyarakat pribumi. Proses ini kemudian menjadi latar belakang percampuran budaya yang mempolakan suatu sistem masyarakat multikultural dalam satu teritori tertentu.

Menurut Max Weber, dalam masyarakat multikultural ada beberapa macam kelompok sosial. Kelompok sosial yang satu berbeda dari kelompok sosial yang lain, walaupun mereka termasuk dalam suatu masyarakat yang sama. Max Weber mengemukakan bahwa kelompok masyarakat majemuk berkaitan dengan tatanan yang mengikat dan dipengaruhi oleh kondisi ekonomi, politik, dan kebudayaan. Masyarakat Indonesia tergolong masyarakat multikultural, yaitu masyarakat yang beragam etnis/suku bangsa, ras, agama, bahasa, adat istiadat, profesi, golongan politik dan sebagainya. Multikulturalisme adalah kesediaan menerima kelompok lain secara sama sebagai kesatuan tanpa memperdulikan perbedaan budaya, etnik, gender, bahasa, ataupun agama. Multikulturalisme memberikan penegasan seseorang atau kelompok bahwa dengan segala perbedaannya diakui dan sama di dalam ruang publik. Multikulturalisme menjadi respon kebijakan baru terhadap keragaman.

Keberagaman suku bangsa dan kebudayaan tersebut, tentu saja berpengaruh terhadap sistem dan struktur sosial. Karena itu, dalam masyarakat Indonesia terdapat bermacam-macam kelompok sosial berdasarkan kriteria tertentu, seperti kelompok sosial yang terbentuk karena kepentingan etnis atau suku bangsa, kelompok sosial karena kepentingan agama, karena kepentingan profesi dan sebagainya. Perkembangan kelompok sosial itu terjadi melalui 2 proses, yaitu proses yang bersifat alami dan disengaja.

Masing-masing masyarakat dengan identitas etnis tertentu menempati wilayah-wilayah yang secara turun-temurun mereka akui sebagai wilayah tempat sumber-sumber kehidupan mereka yang menjadi haknya dan yang hak tersebut diakui oleh suku bangsa lainnya. Masing-masing suku bangsa mengembangkan kebudayaannya sesuai dengan corak dan potensi-potensi sumber daya dalam lingkungan hidup masing- masing dan sesuai dengan tema-tema budaya atau pandangan hidup dan etos yang dipunyai. Oleh karena itu masing-masing kelompok masyarakat mempunyai corak kebudayaan yang berbeda satu dengan lainnya. ${ }^{15}$

Pada umumnya kelompok masyarakat yang beramai-ramai berpindah tempat tinggal ke daerah lain atau kota-kota besar beralasan karena faktor ekonomi atau dengan kata awam "perbaikan nasib". Kota Metro misalnya dapat dijelaskan merupakan salah satu daerah yang pernah menjadi sasaran program transmigrasi pada masa orde baru, tetapi bukan hanya faktor tersebut yang dapat kita telaah. Namun seperti pada umumnya mengenai fenomena perpindahan dan penyebaran penduduk ada berbagai analisis yang dapat kita gunakan sebagai alat kaji, termasuk persoalan sistem masyarakat Indonesia dan budaya kelompok-kelompok etnis yang menyebar di Indonesia.

Kelompok masyarakat pendatang: Etnis Tionghoa, Etnis Jawa, Etnis Padang, dan lain-lain. Mobilitas masyarakat pendatang berlaku secara geografi, yaitu perpindahan dari satu tempat ke tempat lainnya tergantung pada adanya jenis pekerjaan yang lebih menguntungkan; dan juga berlaku dalam pengertian naiknya status sosial-ekonomi bersamaan dengan naiknya tingkat pendapatan mereka. Mereka yang secara mudah berpindah tempat adalah para bujangan, baik laki-laki atau perempuan; sedangkan yang cenderung untuk naik ke jenjang sosialekonomi yang lebih tinggi adalah mereka yang telah berkeluarga.

Sekilas sejarah tentang etnis Tionghoa di Indonesia yang disadur dari salah satu buku "Pemikiran Politik Etnis Tionghoa Indonesia", etnis Tionghoa masuk ke Indonesia dalam tiga tahap, mulai dari masa kerajaan, kedatangan bangsa Eropa, dan kolonial Belanda. Awal kedatangan etnis Tionghoa pada abad ke-16 masa kerajaan Sriwijaya. Mereka datang dengan misi perdagangan dan kita juga sering mendengar istilah "jalur sutera". Hal ini dikarenakan komoditi yang dibawa yaitu kain sutera dan barangbarang yang terbuat dari keramik. ${ }^{16}$

Etnis Tionghoa di era kolonisasi sebagai kelompok non-pribumi masih sedikit lebih beruntung dibandingkan dengan kondisi masyarakat pribumi

15 Parsudi Suparlan. (1985). "Kebudayaan dan Pembangunan". Media IKA. Vol. 14 No. 11. Jurusan Antropologi Universitas Indonesia, h. 6.

16 Leo Suryadinata. (2005). Pemikiran Politik Etnis Tionghoa Indonesia. Jakarta: LP3ES, h. 2. 
yang terdiskriminasi oleh penjajah Belanda. Etnis Tionghoa sebagian besar sebagai pedagang yang menjadi relasi para penguasa. Meskipun begitu eksploitasi sumber daya manusia untuk eksplorasi alam Indonesia yang melibatkan etnis Tionghoa dan non-Tionghoa membuat mereka termarginalkan dari sistem kolonisasi Belanda.

Di samping itu, terdapat ciri lain yang menyolok dalam kehidupan masyarakat pendatang, yaitu: kehidupan mereka semata-mata tertuju pada kepentingan memperoleh keuntungan ekonomi (semua kegiatan dan gejala diukur dalam kepentingan keuntungan ekonomi). Sehingga, rumah-rumah dan penataan ruang dalam rumah sebenarnya dibuat secara irit dan ekonomis, yaitu berfungsi majemuk dan tidak tersisa lagi untuk ruang kosong yang hanya berfungsi kegunaan untuk satu kegiatan (ruang makan adalah juga ruang tamu dan juga ruang tidur, misalnya). Hal yang sama juga berlaku dalam hal pemanfaatan ruang-ruang kosong yang ada di halaman rumah, yang dimanfaatkan untuk membuat warung, usaha industri rumah tangga, bengkel, atau kamar-kamar yang dapat dikontrakkan kepada para pendatang baru. Karena perhitungan ekonomi berada di atas perhitungan-perhitungan lainnya, maka juga mereka cenderung untuk tidak memasak makanan mereka sendiri, khususnya bagi yang bujangan, karena waktu memasak kalau mereka hitung lebih mahal daripada kalau membeli makanan di warung (yang juga dapat dihutang).

Masyarakat pendatang juga memilki kecenderungan orientasi kepentingan ekonomi, yaitu menunjukkan status sosial dengan simbol-simbol "mewah" (pakaian, make-up) yang dapat mereka beli sesuai dengan tingkat pendapatan mereka. Cara mendapatkan barang-barang tersebut yang umum adalah dengan melalui hutang atau kredit. Yang penting barangnya dahulu, membayarkan belakangan, dan kalau perlu juga menghindarkan diri dari pembayaran hutang atau kredit yang menjadi tanggungjawabnya.

Salah satu dari cara hidup di Kota Metro yang mereka ikuti adalah orientasi kepentingan ekonomi. Tetapi tidak semua yang secara tradisional mereka ikuti sebagai pedoman hidup itu tidak fungsional kegunaannya dalam menghadapi tantangan hidup di Kota Metro. Salah satu yang tetap lestari adalah hubungan kekerabatan, hubungan seasal, dan hubungan bapak-anak. Sehingga melahirkan ciriciri utama dari masyarakat pendatang di Kota Metro, khususnya yang tinggal di pemukimanpemukiman liar atau perkampungan yang tergolong berpenghasilan rendah, yaitu hubungan patron-klien (hubungan bapak-pelindung dengan anak yang dilindungi) yang bukan merupakan hubungan formal tetapi hubungan yang informal, sosial, dan spontan.

Kebudayaan mengenal ruang dan tempat tumbuh kembangnya, dengan mengalami perubahan penambahan dan pengurangan. Manusia tidak berada pada dua tempat atau ruang sekaligus, ia hanya dapat pindah ke ruang lain pada masa lain. Pergerakan ini telah berakibat pada persebaran kebudayaan, dan masa ke masa, dan dari tempat ke tempat lain. Sebagai akibatnya di berbagai tempat dan waktu yang berlainan, dimungkinkan adanya unsur-unsur persamaan di samping perbedaan- perbedaan. Oleh karena itu di luar masanya, suatu kebudayaan dapat dipandang ketinggalan zaman (anakronistik), dan di luar tempatnya dipandang asing atau janggal.

\section{Keadaan Sosial Budaya dan Agama di Kota Metro}

Adat istiadat yang sampai sekarang hidup di kalangan masyarakat penduduk Kota Metro secara garis besar dapat digolongkan menjadi dua bagian, yaitu penduduk asli Lampung dan penduduk pendatang. Para penduduk ini tersebar di seluruh Kecamatan yang ada di Kota Metro. Beragamnya etnis menyebabkan keragam pula adat dan kebiasaan masyarakat sesuai dengan daerah asalnya. Beberapa etnis memiliki perkumpulan tertentu yang dinamakan Paguyuban, yang bertujuan untuk mempererat tali persaudaraan seperti etnis Sumatera Barat dengan istilah Keluarga Besar Sumatera Barat (KBSB), etnis Jawa dengan Keluarga Banyumas yang menggunakan istilah penginyongan, dan etnis Tionghoa dengan istilah Paguyuban Sosial Masyarakat Tionghoa Indonesia (PSMTI) atau dalam bahasa Mandarin dikenal dengan Lan Fo.

\section{Politik Etnik Masyarakat Pendatang di Kota Metro}

Pada bagian ini akan diuraikan mengenai politik etnik masyarakat pendatang dalam arena legislatif di Kota Metro. Politik etnik yang dimaksud mengenai karakteristik masyarakat pendatang di Kota Metro, serta peran etnis pendatang dalam arena legislatif. 
Uraian ini dimaksud untuk mendapatkan deskripsi dan pengetahuan mengenai kedua hal tersebut. Pertama, gambaran mengenai karakter masyarakat pendatang dalam kehidupan sosial di Kota Metro. Kedua, peran masyarakat pendatang dalam pemilihan anggota DPRD Kota Metro.

Dalam memahami politik etnik yang terjadi dalam proses tersebut, maka penelitian ini pada dasarnya memperoleh gambaran dari berbagai informasi yang tidak terlepas dari sikap, perilaku, dan partisipasi individu. Setiap individu memiliki orientasi pada situasi politik yang mereka peroleh dari pengetahuan maupun pengalaman dan dipengaruhi oleh perasaan keterlibatan, kesadaran pengeluaran atau pemasukan dalam kelompok, dalam hal ini kelompok etnik. Situasi politik itu sendiri memiliki cakupan yang sangat luas antara lain respon emosional, dukungan atau sikap apatis, kesadaran bahwa ada keterkaitan politik dengan kelompok etniknya.

\section{Keadaan Penduduk Kota Metro}

Keadaan Penduduk Berdasarkan Kecamatan dan Agama yang Dianut

Agama yang dianut penduduk Kota Metro terdiri dari berbagai macam agama, namun dengan demikian yang dominan penduduk Kota Metro menganut agama Islam. Secara rinci jumlah penduduk Kota Metro berdasarkan agama yang dianut dapat dilihat pada Tabel 1.

Tabel 1 tersebut menunjukkan bahwa agama Islam paling banyak dianut di daerah penelitian pada kasus ini yaitu: Metro Timur dan Metro Pusat. Pada urutan berikutnya yaitu agama Protestan dan Katolik. Namun dapat dipahami bahwa di Kota Metro, khususnya di Kecamatan Metro Timur dan Metro Pusat, agama yang dianut penduduknya sudah memiliki keragaman yang cukup komplek.
Tabel 2. Keadaan Penduduk Berdasar Suku Bangsa

\begin{tabular}{lrrr}
\hline Suku Bangsa & \multicolumn{1}{c}{ L } & \multicolumn{1}{c}{ P } & \multicolumn{1}{c}{$\begin{array}{l}\text { Jumlah } \\
\text { (Orang) }\end{array}$} \\
\hline Lampung & 1.267 & 1.262 & 2.529 \\
Jawa & 3.815 & 3.695 & 7.510 \\
Sunda & 247 & 246 & 493 \\
Palembang & 169 & 164 & 333 \\
Padang & 557 & 438 & 995 \\
Bali & 37 & 35 & 72 \\
Tapanuli & 23 & 19 & 42 \\
Lain-lain & 1.584 & 1.585 & 3.169 \\
\hline Jumlah & $\mathbf{7 . 5 2 3}$ & $\mathbf{7 . 3 6 5}$ & $\mathbf{1 5 . 1 4 3}$ \\
\hline Sumber: &
\end{tabular}

Sumber: Monografi Kelurahan Metro Tahun 2015

Dari Tabel 2 kita dapat melihat bahwa etnis Jawa jumlahnya terbanyak dengan angka 7.510 jiwa, meskipun etnis ini pendatang. Sedangkan etnis Lampung menempati posisi kedua dengan angka 2.529 jiwa. Jadi bila dimasukkan kategori terbanyak maka kedua etnis inilah yang sangat memiliki basis massa yang banyak.

\section{Karakteristik Masyarakat Etnis Pendatang dalam Lingkungan Sosial Politik di Kota Metro}

Manusia selain sebagai makhluk sosial yang beragam baik pada tataran individu maupun (Kelompok etnik, agama, ideologi), manusia juga secara alamiah adalah makhluk politik. Hal ini diungkapkan oleh Aristoteles dalam bukunya Politics. Dalam bahasa aslinya (Latin atau Yunani) disebut "Zoon Politicon". Yang dimaksud Aristoteles adalah politik merupakan keberadaan manusia dalam kehidupan bermasyarakat. Jika dua orang atau lebih berinteraksi satu sama lain dalam menjalani kehidupan di dunia, maka mereka tidak lepas dari keterlibatan dalam hubungan yang bersifat politik. Sebagai makhluk politik kedudukan manusia

Tabel 1. Keadaan Penduduk Berdasarkan Agama yang Dianut

\begin{tabular}{lccccc}
\hline \multicolumn{1}{c}{ Kecamatan } & Islam & Protestan & Katolik & Hindu & Budha \\
\hline Metro Selatan & 14.197 & 234 & 243 & 30 & 5 \\
Metro Barat & 23.854 & 426 & 224 & 91 & 81 \\
Metro Timur & 31.031 & 987 & 1.947 & 181 & 669 \\
Metro Pusat & 51.568 & 1.738 & 1.261 & 72 & 907 \\
Metro Utara & 27.410 & 467 & 611 & 51 & 80 \\
\hline Jumlah & $\mathbf{1 4 8 . 0 6 0}$ & $\mathbf{3 . 8 5 2}$ & $\mathbf{4 . 2 8 6}$ & $\mathbf{4 2 5}$ & $\mathbf{1 . 7 4 2}$ \\
\hline
\end{tabular}

Sumber: BPS Kota Metro Tahun 2015 
dalam masyarakat selalu berusaha untuk memenuhi kebutuhannya dengan memanfaatkan sumbersumber yang dimiliki, sedangkan dalam suatu lingkungan politik manusia akan berusaha untuk meraih kekuasaan atau suatu kedudukan dengan menggunakan sumber-sumber yang dimiliki.

Masyarakat majemuk adalah masyarakat yang terdiri atas kelompok-kelompok, yang tinggal bersama dalam suatu wilayah, tetapi terpisah menurut garis budaya masing-masing. Kemajemukan suatu masyarakat patut dilihat dari dua variabel yaitu kemajemukan budaya dan kemajemukan sosial. Kemajemukan budaya ditentukan oleh indikatorindikator genetik-sosial (ras, etnis, suku), budaya (kultur, nilai, kebiasaan), bahasa, agama, kasta, atau pun wilayah. Kemajemukan sosial ditentukan indikator-indikator seperti kelas, status, lembaga, atau pun power.

Masyarakat Kota Metro terdiri dari beberapa etnis yang hidup berdampingan seperti etnik Tionghoa, etnis Jawa, etnis Padang dan diikuti beberapa subsub etnik kecil yakni Bali, Banten, dan Sunda. Adapun etnis Banten yang jumlahnya relatif kecil hanya terdapat di daerah seputaran pasar saja, karena pada umumnya mereka bekerja di pasar. Penduduk Kota Metro dalam kehidupan sehari-harinya, masih banyak yang terikat sistem norma dan aturan-aturan yang menjadi falsafah hidup bagi masyarakat Kota Metro terutama etnis pendatang.

Berbicara tentang Metro maka adalah identik pula dengan suku Lampung. Istilah Lampung adalah istilah yang diciptakan oleh masyarakat Lampung itu sendiri. Kata Lampung berasal dari kata "anjak lambung" yang berarti berasal dari ketinggian dan seperti diketahui bahwa kaki gunung Pesagi dan dataran tinggi Sekala Brak, Lampung Barat yang menjadi tempat asal mula suku Lampung. Ulun Lampung adalah puncak tertinggi di tanah Lampung. Karena kebutuhan untuk memenuhi hidup yang sudah tidak terpenuhi lagi di dataran tinggi Sekala Brak, maka kelompok demi kelompok meninggalkan Sakala Berak menurun ke lembah dengan mengikuti aliran sungai. Kelompok atau kaum tersebut kemudian membentuk buwai.

Catatan lain menyebutkan bahwa perpindahan suku asli Lampung disebabkan adanya penyerangan dari luar, sebagaimana dijelaskan dalam Kitab Kuntara Raja Niti, bahwa orang-orang Bajau (perompak laut) datang menyerang, akhirnya Keratuan Pemanggilan menjadi pecah. Sedangkan warganya beralih tempat meninggalkan Sekala Berak menuju ke daerah dataran rendah Lampung sekarang.

Sejak saat itu, Ulun Lampung menjadi beberapa buwai yang kemudian menjadi Sub-Suku Lampung seperti sekarang ini, yaitu Komering, Peminggir Teluk/Semangka/Pemanggilan, Melinting/Meninting, Way Kanan, Sungkai, Pubian, Abung, dan Tulang Bawang. Termasuk juga Ranau dan Lampung Cikoneng. Catatan asal usul ini masih sangat perlu didukung data-data autentik dan tersurat dalam catatan/dokumen yang tertulis di kulit-kulit pohon yang mungkin banyak tersimpan seantero Kampung Tua yang ada di Lampung. Termasuk di daerah Ranau maupun Komering.

Adat istiadat Pepadun dianut oleh orang-orang Lampung yang bertempat kediamannya dahulu meliputi Abung Way Kanan atau Sungkai Tulang Bawang dan Pubian. Sedangkan adat istiadat Saibatin dianut oleh orang-orang Lampung yang bertempat kediamannya dahulu meliputi daerah di sepanjang pantai Pesisir Teluk Lampung, Teluk Lampung, Teluk Semangka, Krui, Belalau. ${ }^{17}$

Dalam masyarakat Lampung ada dua masyarakat yaitu masyarakat Lampung Saibatin dan masyarakat Lampung Pepadun. Masyarakat Lampung Saibatin mendiami daerah pesisir Lampung yang membentang dari timur, selatan, hingga barat. Wilayah persebaran Suku Saibatin mencakup Lampung Timur, Lampung Selatan, Bandar Lampung, Pesawaran, Tanggamus, dan Lampung Barat. Seperti juga Suku Pepadun, Suku Saibatin atau Peminggir menganut sistem kekerabatan patrilineal atau mengikuti garis keturunan ayah. Meski demikian, Masyarakat Lampung Saibatin memiliki kekhasan dalam hal tatanan masyarakat dan tradisi.

"Saibatin" bermakna satu batin atau memiliki satu junjungan. Hal ini sesuai dengan tatanan sosial dalam masyarakat Lampung Saibatin, hanya ada satu raja adat dalam setiap generasi kepemimpinan. Budaya masyarakat Lampung Saibatin, cenderung bersifat aristokratis karena kedudukan adat hanya dapat diwariskan melalui garis keturunan. Tidak seperti masyarakat Lampung Pepadun, tidak ada

${ }^{17}$ Depdikbud. (1981/1982). Upacara Tradisional Daerah Lampung, Proyek Inventarisasi dan Dokumentasi Daerah Lampung. Bandar Lampung: Kanwil Propinsi Lampung, h. 5. 
upacara tertentu yang dapat mengubah status sosial seseorang dalam masyarakat. Pendapat lain dikemukakan oleh Ali Imron berikut ini: Saibatin merupakan sebutan kepada salah satu suku asli Lampung yang berasal dari Sekala Berak. Kemudian menebar kewilayah pantai atau Pesisir Barat ujung Pulau Sumatera. Di mana Sai artinya satu = jiwa, jadi dapat diartikan Saibatin merupakan satu jiwa atau satu batin. Aplikasi satu batin ini di dalam adat, bermakna kepemimpinan atau punyimbamg tidak pernah berpindah ke genenerasi yang lain apalagi ke suku orang lain. ${ }^{18}$

Disini dijelaskan yang dimaksud dengan Saibatin adalah yang memimpin dengan ciri-ciri: Martabat kedudukan Adat tetap, tidak ada upacara peralihan Adat; Jenjang kedudukan Saibatin tanpa tahta; Bentuk perkawinan Jujor dan Semanda; Pakaian Adat hanya dimiliki dan dikuasai Saibatin Siger (Mahkota) sebelah; Kebanggaan keturunan hanya terbatas pada kekerabatan Saibatin; Hubungan kekerabatan kurang akrab; Belum diketahui kitab-kitab peganganpegangan adat; Pengaruh Islam kebih kuat; Peradilan adat mulai lemah. ${ }^{19}$

Ciri lain dari Suku Saibatin dapat dilihat dari perangkat yang digunakan dalam ritual adat. Salah satunya adalah bentuk siger (sigekh) atau mahkota pengantin Suku Saibatin yang memiliki tujuh lekuk/pucuk (sigokh lekuk pitu). Tujuh pucuk ini melambangkan tujuh adoq, yaitu suttan, raja jukuan/ depati, batin, radin, minak, kimas, dan mas. Selain itu, ada pula yang disebut awan gemisir (awan gemisikh) yang diduga digunakan sebagai bagian dari arak-arakan adat, diantaranya dalam prosesi pernikahan.

\section{Peran Etnis Pendatang dalam Arena Politik Pemilihan Anggota DPRD di Kota Metro}

Etnopolitik atau politik etnis dapat diasumsikan sebagai politik yang memfokuskan pembedaan sebagai kategori utamanya yang menjanjikan kebebasan dan toleransi. Munculnya politik etnis diawali tumbuhnya kesadaran orang yang mengidentikan diri mereka ke dalam salah satu kelompok etnis tertentu, yang kesadaran itu memunculkan solidaritas kelompok.

\footnotetext{
${ }^{18}$ Ali Imron. (2005). Pola Perkawinan Saibatin. Bandar Lampung: Universitas Lampung, h. 100.

${ }^{19}$ Hilman Hadikusuma. (1989). Masyarakat dan Adat Budaya Lampung. Bandung: Mandar Maju, h. 119.
}

Seperti yang diungkapkan Bapak Lilik: "kesamaan suku dan budaya yang dimiliki secara tidak langsung ada ikatan emosional untuk saling tolong-menolong di tanah rantau". ${ }^{20}$

Sejalan dengan demokratisasi di Indonesia sering timbul pemikiran-pemikiran yang mementingkan kelompok dan suku sendiri (sukuisme), adanya kecenderungan untuk menggunakan nilai-nilai kelompok dalam proses politik. Maraknya proses demokrasi yang ditandai dengan desentralisasi, di mana pemerintah pusat memberi otonomi kepada pemerintah daerah untuk memperoleh kebebasan dan pengakuan politik dalam pemilihan kepala daerah sendiri. Etnisitas yang menjadi ikatan yang sangat emosional dan mengakar dalam masingmasing individu dalam etnisnya, telah memicu munculnya perjuangan kelompok-kelompok etnis dari dominasi etnis mayoritas. Etnisitas berkaitan erat dengan budaya masing-masing kelompok yang memiliki ciri khas kelompok tersebut atau yang sering disebut dengan primordialisme. Sehingga tidak jarang keterikatan etnis ini sering dimanfaatkan dan dimanipulasi kelompok elite (aktor-aktor politik) untuk mencapai tujuan dan mendapatkan kekuasaannya, terutama di daerah yang penduduknya heterogen.

Setelah sistem electoral dilakukan secara langsung, baik untuk pemilihan Kepala Daerah dan pemilihan DPRD, muncul sebuah indikasi telah terjadi pergeseran politik yang dikembangkan oleh etnis pendatang. Kekuatan lobby maupun kekuatan finansial saat ini dirasakan tidak cukup lagi untuk mengontrol berbagai kebijakan politik di tengah rumitnya dinamika politik lokal di Kota Metro. Ada semacam keharusan bahwa etnis harus terlibat langsung dalam sistem politik formal jika ingin melakukan perubahan secara cepat di tengah arus perubahan politik, sekaligus sebagai upaya menanggalkan image sebagai etnis perantara yang cenderung dipolitisasi dari berbagai kepentingan politik.

Etnis pendatang untuk menempatkan wakilnya dalam pemilu legislatif di Kota Metro mengisyaratkan bahwa mereka mulai menuai hasil dari perubahan strategi politik yang mereka kembangkan. Dari hasil penelitian ditemukan bahwa perpolitikan di Kota

\footnotetext{
${ }^{20}$ Wawancara dengan Bapak Lilik selaku tokoh masyarakat di Iring Mulyo Metro Timur pada 1 Juni 2017.
} 
Metro masih menggunakan kekuatan primordial sebagai basis pergerakan politik. Sistem kekerabatan yang terbangun sejak lama seperti, adanya kesamaan profesi (pengusaha), jejaring kekerabatan organisasi baik dari segi agama maupun suku dikonversi dengan baik sebagai modal untuk berkompetisi dengan mayoritas etnis yang lain sehingga memunculkan sebuah sistem politik kekerabatan.

Sebenarnya etnis pendatang juga ingin menggunakan kekuatan primordial keterwakilan politik di tingkat parlemen lokal diharapkan mampu mengatasi berbagai masalah yang selama ini membelenggu pendatang. Namun dari segi kuantitas masih tergolong kecil.

Keikutsertaan warga negara dalam pemilu merupakan serangkaian kegiatan membuat keputusan, yakni apakah akan memilih atau tidak memilih dalam pemilu. Dengan melihat pola perilaku pemilih, kita dapat mengetahui apakah pemilih memilih berdasarkan manifesto partai atau tertarik hanya berdasarkan emosional belaka.

Tindakan atau keputusan politik seseorang ditentukan oleh perilaku, sikap dan persepsi politik. Perilaku politik adalah pikiran dan tindakan yang berkaitan dengan pemerintah. Perilaku politik ini meliputi tanggapan-tanggapan internal seperti persepsi, sikap dan keyakinan, juga meliputi tindakan yang nyata seperti pemberian suara, protes, lobbying, dan lain sebagainya. Sedangkan persepsi politik berkaitan dengan gambaran suatu objek tertentu, baik mengenai keterangan maupun informasi dari suatu hal maupun gambaran tentang objek politik yang bersifat fisik dan nyata. Dan sikap politik berkaitan dengan berbagai keyakinan yang telah melekat dan mendorong seseorang untuk menanggapi suatu objek atau situasi politik dengan suatu cara tertentu.

Terkait dengan peran masyarakat pendatang dalam pemilu tidak terlepas dengan konsep membangun masyarakat yang berdaya oleh pemerintah. Bahwa peran pemerintah dalam hal ini dapat ditunjukan dengan membuka ruangruang publik dan informasi yang dapat diakses oleh masyarakat luas, sehingga masyarakat mampu berpartisipasi dalam setiap kebijakan yang dibuat, melalui partisipasi harapannya adalah masyarakat mampu menjadi mitra pemerintah tentunya partisipasi dibangun atas dasar kebebasan berasosiasi dan berbicara secara konstruktif. Kaitannya dengan pemilu legislatif, partisipasi terwakilkan secara baik dalam model dan sistem secara terbuka, setiap orang untuk bisa berpartisipasi penuh dalam hal dipilih maupun memilih. Seperti yang dikatakan Basuki: "Pemilu legislatif, adalah kesempatan kita untuk memilih dan dipilih, tanpa memilih dengan ikhlas, dan dipilih berdasarkan kualitas, bukan semata karena kesamaan etnis". ${ }^{21}$

Sebenarnya situasi tersebut menuju ke arah yang positif, yaitu penguatan kesetaraan (egality) dalam hak-hak individu diakui. Hal ini juga menguatkan demokratisasi yang sedang terbangun. Namun, penulis memiliki catatan kritis dengan kondisi yang ada. Bahwa dengan banyaknya partisipasi masyarakat yang mendaftarkan diri menjadi calon legislatif (caleg), maka masyarakat sebagai yang memilih hanya dijadikan sasaran untuk memenuhi hasrat kemenangan, sehingga dalam pelaksanaannya cara apapun akan dilakukan oleh sang caleg demi meraih kemenangan. Karena itu sudah tidak aneh jika saat ini kita melihat banyak caleg memberikan uang atau barang lainnya untuk meyakinkan masyarakat untuk memilihnya dan parahnya masyarakat terbuai dengan pemberian sang caleg, sehingga terbangun paradigma musim kampanye ini adalah musimnya bagi-bagi uang atau barang bukan untuk mengagendakan perubahan.

Apabila kita lihat lebih jauh, ketimpangan antara harapan dan kenyataan benar-benar terjadi. Masyarakat dijadikan komoditas politik saja bukan sebagai aktor yang harusnya bersikap kritis terhadap kondisi tersebut.

Lembaga-lembaga publik non negara atau disebut Civil Society Organization (CSO) seperti Lembaga Swadaya Masyarakat (LSM), media massa, Perguruan Tinggi sebagai lembaga yang memiliki akses terhadap pemerintahan harus dimaksimalkan kembali. De tecquevill mendefinisikan civil society sebagai wilayah kehidupan sosial yang mandiri yang bercirikan kesukarelaan, keswasembadaan, dan keswadayaan yang didalamnya terdapat masyarakat yang kuat ketika berhadapan dengan negara. Kekuatan tersebut masih dalam lingkup masyarakat mentaati norma-norma atau aturan yang berlaku.

Kaitannya dengan mewujudkan kedaulatan rakyat dalam pemilu, pengawasan terhadap setiap

${ }^{21}$ Wawancara dengan Bapak Basuki salah satu caleg terpilih dari wilayah Iringmulyo Metro Timur pada 2 Juni 2017. 
calon anggota legislatif mutlak harus dilakukan oleh masyarakat yang terintegrasi dalam lembaga-lembaga non negara Civil Society Organization (CSO). Adapun bentuk pengawasan yang dapat dilakukan Civil Society Organization (CSO) dalam mewujudkan kedaulatan masyarakat adalah lembaga-lembaga publik non negara atau Civil Society Organization (CSO) seperti Lembaga Swadaya Masyarakat, media massa, Perguruan Tinggi dapat melakukan pendidikan kepada masyarakat luas, pengawasan publik serta pembelaan (advokasi) masyarakat. Patut disadari bahwa hampir mayoritas penduduk Indonesia masih rendah tingkat pendidikannya, sehingga dengan adanya pendidikan politik ini diharapkan masyarakat dapat mengetahui hak-hak politiknya secara sadar sehinga rasional dalam menentukan pilihannya kelak. Selain itu juga, setiap calon yang ada perlu dibangun komitmennya dalam bentuk kontrak politik terhadap masyarakat, sehingga janji-janji yang diucapkan pada saat kampanye dapat dipantau untuk diselaraskan dengan kinerjanya.

Adapun pembelaan terhadap masyarakat dapat dilakukan sebagai wujud pendampingan terhadap hakhak politik masyarakat, sehingga setiap calon yang ingin maju tidak bisa sewenang-wenang terhadap masyarakat. Pada akhirnya dalam membangun hubungan antara masyarakat dengan calon anggota legislatif pada masa kampanye ini harus dimulai dari dalam masyarakat, sehingga tercipta sinergitas antara kebutuhan masyarakat dengan kinerja calon jika terpilih nanti. Hanya masyarakat yang mampu mengetahui hak-hak politiknya secara sadar nantinya memiliki posisi tawar (bargaining position) yang tinggi terhadap sang calon, sehingga agenda perubahan yang dicita-citakan dapat diwujudkan.

\section{PENUTUP}

\section{Kesimpulan}

Beragamnya suku bangsa, adat serta agama yang dimiliki oleh Indonesia yang masing-masing budaya memiliki khasnya masing masing, telah memunculkan perilaku politik yang berbeda-beda. Salah satu kota dengan percampuran etnis sehingga tercipta suatu multikulturalis yang harmonis yaitu Kota Metro. Etnis pendatang (Tionghoa, Jawa, Banten, dan Sunda) sama-sama melakukan proses interaksi sosial dengan masyarakat asli. Karakteristik masyarakat sosial politik pendatang di Kota Metro masih cenderung membuat kelompok berdasarkan ikatan emosional ini terjadi oleh karena kesamaan yang mereka miliki, namun proses pembauran dengan interaksi lingkungan sosial berjalan baik. Masyarakat pendatang di Kota Metro lebih banyak menaruh perhatian di segi ekonomi, dari sisi politik mereka mendukung sistem politik lewat berpartisipasi aktif dalam pemilihan legislatif di Kota Metro. Namun kesadaraan akan jumlah kuantitas mereka masih kalah bersaing dalam perebutan kursi di parlemen. Di Kota Metro yang tingkat kemajemukan etnisnya tinggi, posisi sentra kekuasaan politik masih dipegang oleh masyarakat asli. Namun keikutsertaan mereka baik memilih dan dipilih memiliki peran terhadap sistem politik. Kehadiran mereka dalam politik telah menunjukan usaha untuk dapat bersaing dan bersama masyarakat asli memajukan Kota Metro di berbagai aspek kehidupan.

\section{Rekomendasi}

Dari kenyataan tersebut dirasakan belum terjadi upaya maksimal dari masyarakat dalam membangun pondasi politik yang kuat untuk masa selanjutnya. Membangun sebuah masyarakat yang mandiri dan berdaya tentunya tidak semudah membalikkan telapak tangan, diperlukan sebuah keseriusan seluruh elemen yang terkait terutama dari dalam masyarakat itu sendiri. Strategi yang dapat dilakukan ialah masyarakat harus berani mengintegrasikan dirinya menjadi sebuah kekuatan dalam bentuk lembaga atau pun organisasi, sehingga memiliki daya tawar tinggi ketika berhadapan dengan negara. Artinya, tingkah laku politik merupakan pencerminan dari budaya politik suatu masyarakat yang penuh dengan aneka bentuk kelompok dengan berbagai macam tingkah lakunya. Bertemunya dua atau lebih etnis pada satu daerah membutuhkan penyesuaian satu dengan yang lain, proses penyesuaian dalam proses interaksi.

\section{DAFTAR PUSTAKA}

\section{Buku:}

Ali Imron. (2005). Pola Perkawinan Saibatin. Bandar Lampung: Universitas Lampung.

Alo Liliweri. (2005). Prasangka dan Konflik. Yogyakarta: LKiS.

Amin Abdullah. (2005). Pendidikan Multikultural. Yogyakarta: Pilar Media. 
B. Ahmad Soebani. (2009). Metode Penelitian Hukum. Bandung: Pustaka Setia.

Depdikbud. (1981/1982). Upacara Tradisional Daerah Lampung, Proyek Inventarisasi dan Dokumentasi Daerah Lampung. Bandar Lampung: Kanwil Propinsi Lampung.

Efriza. (2012). Political Explore: Sebuah Kajian Ilmu Politik. Bandung: Alfabeta.

Hilman Hadikusuma. (1989). Masyarakat dan Adat Budaya Lampung. Bandung: Mandar Maju.

Irawan Soehartono. (1999). Metode Penelitian Sosial Suatu Teknik Penelitian Bidang Kesejahteraan Sosial Lainnya. Bandung: Remaja Rosda Karya.

James D. Fearon. (2004). Ethnic Mobilization and Ethnic Violence. Departement of Political Science Stanford University.

Jean Kristiadi. (2006). Pemilihan Umum dan Perilaku Pemilih di Indonesia. Jakarta: Prisma.

Leo Suryadinata. (2005). Pemikiran Politik Etnis Tionghoa Indonesia. Jakarta: LP3ES.

Lexy Moleong. (2000). Metodologi Penelitian Kualitatif. Bandung: Remaja Rosda Karya.

Muhammad Asfar. (2006). Pemilu dan Perilaku Memilih 1955-2004. Surabaya: Pustaka Eureka.

Noeng Muhajir. (1989). Metode Penelitian Kuantitatif. Jakarta: Rake Sarasin.
Oka Mahendra. (2005). Pilkada di Tengah Konflik Horizontal. Jakarta: Millenium Publisher, h. 41.

Rusmin Tumanggor dkk. (2010). Ilmu Sosial dan Budaya Dasar. Jakarta: Kencana.

Samuel P. Hutington dkk. (2010). Partisipasi Politik di Negara Berkembang. Jakarta: Rineka.

\section{Jurnal:}

Parsudi Suparlan. (1985). "Kebudayaan dan Pembangunan”. Media IKA. Vol. 14 No. 11. Jurusan Antropologi Universitas Indonesia.

\section{Makalah dan Wawancara:}

Parsudi Suparlan. "Masyarakat Majemuk, Masyarakat Multikultural dan Minorotas". Makalah. Dalam Workshop Yayasan Interseksi "Hak-hak Minoritas dalam Landscape Multikultural” pada tanggal 5 Desember 2016.

Wawancara dengan Bapak Basuki salah satu caleg terpilih dari wilayah Iringmulyo Metro Timur pada 2 Juni 2017.

Wawancara dengan Bapak Lilik selaku tokoh masyarakat di Iring Mulyo Metro Timur pada 1 Juni 2017. 